\title{
ANALISIS STRUKTUR, TEKSTUR DAN PERMASALAHAN POLITIS WAYANG BEBER JAKA KEMBANG KUNING
}

\author{
Wahid Nurcahyono \\ Institut Seni Indonesia Yogyakarta \\ Waheed151@gmail.com
}

\begin{abstract}
Abstrak: Hasil penelitian ini berguna untuk melihat bentuk pementasan serta persoalan yang melingkupi sebuah bentuk kesenian bernama Wayang Beber Panji Jaka Kembang Kuning yang berada di Kabupaten Pacitan, Jawa Timur. Dari penelitian ini kita berharap agar keberadaan kesenian ini tidak akan hilang meski harus mengikuti perkembangan selera masyarakat yang terus berubah. Salah satu usaha yang ditempuh adalah menuliskan struktur dan tekstur pertunjukan ini. Dengan mengetahui struktur dan tekstur serta persoalan lain yang melingkupi, maka generasi penerus pertunjukan ini tidak terbentur pada persoalan yang menyebabkan pertunjukan ini semakin dijauhi masyarakat. Dalang atau penyaji pertunjukan bisa menggunakan hasil penelitian ini sebagai pedoman untuk menciptakan pertunjukan yang lebih menarik agar tidak selalu terjebak pada bentuk pertunjukan yang membosankan. Akibatnya penonton akan lebih mudah menikmati dan memahami pertunjukan seni tersebut. Akhirnya Wayang Beber sebagai pertunjukan akan tetap eksis karena mampu hadir dalam konteks masyarakatnya.
\end{abstract}

Kata kunci: Struktur, tekstur, stagnasi, wayang beber, konteks.

\begin{abstract}
The results of this study are useful for observing the form of performances and issues surrounding an art form called Wayang Beber Panji Jaka Kembang Kuning in Pacitan Regency, East Java. From this research we hope that the existence of this art will not be lost even though we have to keep up with the changing tastes of society. One of the efforts taken was to write down the structure and texture of this performance. By knowing the structure and texture as well as other problems that surround it, the next generation of this show will not run into problems that cause this show to be increasingly shunned by the public. The puppeteers or performance presenters can use the results of this research as a guideline for creating more interesting performances so they don't always get stuck in boring performances. As a result, the audience will find it easier to enjoy and understand the art performance. Finally, Wayang Beber as a show will still exist because it is able to be present in the context of its society.
\end{abstract}

Keyword: structure, texture, stagnation, Wayang Beber, context.

\section{Pendahuluan}

Untuk menjadikan Wayang Beberyang berwujud dua dimensi menjadi sebuah karya tiga dimensi perlu dilakukan transformasi ke dalam sebuah pertunjukan. Selama ini sang seniman bercerita secara lisan atau bertutur, cara ini dilakukan secara turun temurun. Tradisi lisan dapat diartikan sebagai kebiasaan atau adat yang berkembang dalam suatu komunitas masyarakat yang direkam dan diwariskan dari generasi ke generasi melalui bahasa lisan. Dalam tradisi lisan terkandung kejadian-kejadian sejarah, adat istiadat, cerita, dongeng, peribahasa, lagu, mantra, nilai moral, dan nilai keagamaan, seperti halnya Wayang Beber ini. Perkembangan tradisi lisan terjadi dari mulut 
ke mulut sehingga menimbulkan banyak versi cerita. Tradisi lisan mencakup beberapa hal, yakni (1) yang berupa kesusastraan lisan, (2) yang berupa teknologi tradisional, (3) yang berupa pengetahuan folklore di luar pusat-pusat istana dan kota metropolitan, (4) yang berupa unsur-unsur religi dan kepercayaan folklore di luar batas formal agama-agama besar, (5) yang berupa kesenian folklore di luar pusat-pusat istana dan kota metropolitan, dan (6) yang berupa hukum adat (Hutomo, 1991).

Setelah Mbah Mardi (seorang dalang Wayang Beber pewaris) meninggal sempat beberapa waktu belum ada penerusnya secara berkesinambungan, sehingga terjadi polemik perebutan artefak antara anggota keluarga sendiri. Sampai saat ini, Mbah Mardi dianggap merupakan satu-satunya dalang Wayang Beber di Pacitan yang juga memiliki Wayang Beber warisan leluhurnya. Menurut penuturan keluarganya, Wayang Beber yang dimilikinya ini adalah warisan leluhur turuntemurun yang merupakan hadiah dari Raja Brawijaya. Wayang Beber Pacitan saat ini identik milik ahli waris $\mathrm{Ki}$ Sarnen Gunacarita. Di mata anak-cucu Ki Sarnen, artefak Wayang Beber yang satu satunya ada di Pacitan itu adalah pusaka keluarga. Mereka amat mengeramatkan dan tidak sembarang orang bisa melihatnya (Sutyastomo, 2013, p. 59).

Silsilah pemilik sekaligus dalang dari Wayang Beber adalah sebagai berikut:

1. Naladerma

8. Poleksono

2. Nalongso

9. Dipoleksono

3. Citrow ongso

10. Poleksono

4. Gondoyuto

11. Posetiko

5. Singononggo

6. Trunodongso

12. Gunocarito / Sarnen

7. Gondoleksono

13. Sumardi
Mbah Mardi menjadi dalang sejak tahun 1982 dan meningal dunia pada tahun 2014 lalu. Namun, justru lebih banyak daerah luar kota Pacitan yang masih menggelar Wayang Beber ini. Wayang Beber cukup populer di manca negara, misalnya di Jepang, Belanda, dan Perancis. Seorang ilmuwan Perancis juga pernah meneliti bahan yang dipakai untuk mewarnai gulungan kertas Wayang Beber yang ternyata berasal dari getah-getahan, tutur Supani (salah seorang anggota keluarga mbah Mardi yang sekarang meneruskan tradisi mementaskan Wayang Beber ini)

Cerita dalam Wayang Beber sendiri mulai mendapat perhatian yang khusus bagi pemerhati seni pertunjukan. Pada konteks tertentu penyaji cerita mendapat tantangan untuk membawakan cerita sehingga bisa dinikmati masyarakat saat ini. Melalui pertunjukan Wayang Beber itu cerita di dalamnya diuji daya tariknya. Begitu peristiwa teater dikembalikan ke kondisi semula, maka konsep kepengarangan individual (penulis drama) juga ditantang, sebab sebuah peristiwa teater menghendaki kolaborasi pemain-pemain, sutradara, staf teknis, dan sebagainya yang kesemuanya berperan memberikan kontribusi ke penciptaan peristiwa teater itu sendiri (Sahid, 2008, p. 28). Penulis drama dalam hal ini bukan saja pelukis Wayang Beber akan tetapi juga sang dalang itu sendiri dengan menggunakan lisannya secara langsung saat pementasan.

Kesadaran generasi muda untuk melestarikan bentuk kesenian ini lumayan tinggi, namun karena terbentur dengan aturan tradisional tersebut maka menjadi sulit bagi generasi penerus untuk memainkannya. Oleh karena aturan dalam pementasan kesenian tertutup maka perlu kiranya dibuat sebuah gambaran yang jelas mengenai bagaimana tata cara pementasan Wayang Beber. Jika telah ditentukan aturan dan dramaturgi 
pementasannya maka akan mudah bagi masyarakat seni untuk memainkannya. Karena sebuah kesenian merupakan identitas bagi pendukungnya, maka masyarakat akan melihat bahwa kesenian ini sudah menjadi bagian mereka sendiri dengan sedikit banyak budaya yang melingkupinya. Konteks di mana sebuah karya diciptakan tidak dapat dipisahkan dari karya itu tanpa merampok identitas seninya, maka pemahaman konteks menjadi syarat bagi pengertian wajar arti karya tersebut. Karya-karya seni memiliki daya sebuah teks, sejauh orang dapat membacanya. (Hausteller, 2015, p. 103). Pesan yang terkandung dalam karya seni ini terkandung dalam cerita maupun bentuk pertunjukannya di mana segala unsur permainannya menyerap kebiasaankebiasaan yang dimiliki masyarakat di mana kesenian itu berada. Sang dalang mau tidak mau seringkali menggunakan bahasa dan dialek yang tidak asing bagi lingkungan dimana dia berada.

\section{Tinjauan Pustaka}

Buku Sejarah Wayang Asal-Usul, Jenis, dan Cirinya oleh Amir Mertosedono SH. Melalui buku ini, Amir Mertosedono berbagi pengetahuan seputar wayang yang jenisnya beraneka ragam itu. Ada Wayang Purwa, Wayang Gedhog, Wayang Klithik, Wayang Golek, Wayang Topeng, Wayang Wong (Wayang Orang), dan Wayang Beber. Ada juga Wayang China (Wayang Tithi atau Wayang Potehi), Wayang Klitik (Wayang Krucil), Wayang Kulit dan Wayang Madya. Selain itu juga ada Wayang Wong, Bedhaya Srimpi, Gambyong, Wireng, Pethilan, Bondhan, Golek, Langenwanara, Pranasmara, Topeng, Lerok, Ludruk, Kethoprak (Ketoprak), dan Ludruk.

Pada bab Sejarah Wayang, Amir Mertosedono, memaparkan asal-usul, silsilah, pengertian, dan jenis-jenis wayang. Dari sini terdapat kesimpulan yang syarat rujukan bahwa wayang adalah produk budaya asli bangsa Indonesia. Wayang telah ada dan pernah dipertunjukkan pada zaman kejayaan Kerajaan Kediri yang bertepatan pada zaman pemerintahan Raja Erlangga di awal abad ke-11. Selain itu ada juga yang mengatakan bahwa wayang telah ada pada zaman pemerintahan Prabu Jayabaya di Mamonang pada tahun 930.

Buku Research Design, pendekatan Metode Kualitatif, Kuantitatif, dan campuran oleh John W. Creswell sangat membantu untuk memahami langkah-langkah dalam melakukan penelitian ini. Buku tersebut berisi kerangka kerja, proses, dan aneka pendekatan komposisonal dalam merancang proposal untuk penelitian kualitatif, kuantitatif, dan campuran untuk bidang ilmu sosial humaniora.

Nyoman Kutha Ratna dalam bukunya menyampaikan wacana seputar teori dan metode yang dipergunakan untuk meneliti suatu objek karya sastra. Teori dan metode penelitian dipergunakan untuk memahami segala gejala yang sebelumnya belum nampak. Dalam kesenian Wayang Beber ini tentu saja terdapat unsur-unsur sastra yang perlu kiranya mendapatkan perhatian secara detail agar mampu memperoleh gambaran lebih dalam akan bentuk dramaturgi yang dimaksudkan. Karya sastra dalam hal ini Wayang Beber merupakan bagian yang tak terpisahkan dari kebudayaan yang dihasilkan dari kekayaan imajinasi dan kreatifitas yang hanya mampu ditangkap secara intuitif, oleh karenanya memerlukan pemahaman yang sama sekali berbeda dengan ilmu sosial lainnya

Richard Schechner dalam bukunya, Performance Studies, banyak membahas kedudukan seni pertunjukan serta bagaimana masyarakat melihat sebuah fenomena pertunjukan. Schechner juga membahas fungsi, kedudukan serta bagimana kesenian memberikan sumbangan bagi perkembangan hubungan sosial di masyarakat dari ritual 
menjadi sarana huiburan bahkan bisnis. Tentu pembahasan tersebut sangat penting untuk mempelajari sebuah fenomena pertunjukan semisal Wayang Beber ini.

\section{Landasan Teori}

George R. Kernodle dalam bukunya Invitation to The Theater membahas tentang aspek-aspek pertunjukan dan bagaimana seseorang menciptakannya. Sebuah kwalitas pertunjukan tidak bisa dilepaskan dari kejelian sang creator dalam memandang segala unsur penyusun sebuah karya seni. Bagaimana seorang seniman menyusun setiap elemen pertunjukan yang akan membuat penonton memahami serta menikmati pertunjukan tersebut. Pertunjukan tak bisa lepas dari penonton sebagai pihak yang akan menerimanya. Bagaimana elemen pertunjukan akan berpengaruh terhadap seluruh pertunjukan apabila tidak diukur terlebih dahulu dalam mencampurkannya menjadi satu kesatuan yang utuh dari sebuah permainan. Pemilihan unsur-unsur artistik serta cara menggabungkannya tentu tak bisa dilepaskan dari kepekaaan sang creator karya seni sehingga penonton tidak akan melupakan pertunjukan tersebut dan tentu saja akan menjadi sebuah kesan tersendiri di masyarakat, menjadikannya karya yang akan ditempatkan dihati pemirsanya. Karya seni yang berangkat dari dua dimensi menjadi tiga dimensi tentu membutuhkan penyikapan serta kiat-kiat tersendiri. Maka dalam kesenian Wayang Beber Jaka Kembang Kuning ini nantinya akan ditemukan beberapa persoalan yang harus dihadapi.

Dalam kaitannya dengan masalah Dramaturgi, Goffman menyebut bahwa "ketertiban interaksi" (interaction order) meliputi struktur, proses, dan produk interaksi sosial. Ketertiban interaksi muncul untuk memenuhi Kebutuhan akan pemeliharaan "keutuhan diri", seperti inilah pemikiran kaum interaksionis umumnya. Inti pemikiran Goffman adalah "diri” (self), yang dijabarkan oleh Goffman dengan cara yang unik dan memikat yaitu Teori Diri Ala Goffman (Mulyana, 2004, p. 106).

Fokus pendekatan dramaturgis adalah bukan apa yang orang lakukan, bukan apa yang ingin mereka lakukan, atau mengapa mereka melakukan, melainkan bagaimana mereka melakukannya. Berdasarkan pandangan Kenneth Burke bahwa pemahaman yang layak atas perilaku manusia harus bersandar pada tindakan. Dramaturgi menekankan dimensi ekspresif atau impresif kegiatan manusia. Burke melihat tindakan sebagai konsep dasar dalam dramatisme. Burke memberikan pengertian yang berbeda antara aksi dan gerakan. Aksi terdiri dari tingkah laku yang disengaja dan mempunyai maksud, gerakan adalah perilaku yang mengandung makna dan tidak bertujuan. Masih menurut Burke bahwa seorang dapat melambangkan simbol-simbol. Seseorang dapat berbicara tentang ucapanucapan atau menulis tentang kata-kata, maka bahasa berfungsi sebagai kendaraan untuk aksi. Karena adanya kebutuhan sosial masyarakat untuk bekerja sama dalam aksiaksi mereka, bahasapun membentuk perilaku.

Dramaturgi menekankan dimensi ekspresif atau impresif aktivitas manusia, yakni bahwa makna kegiatan manusia terdapat dalam cara mereka mengekspresikan diri dalam interaksi dengan orang lain yang juga ekspresif. Oleh karena perilaku manusia bersifat ekspresif inilah, maka perilaku manusia bersifat dramatik.

Goffman mendalami dramaturgi dari segi sosiologi, menggali segala macam perilaku interaksi yang kita lakukan dalam pertunjukan kehidupan kita sehari-hari yang menampilkan diri kita sendiri dalam cara yang sama dengan cara seorang aktor menampilkan karakter orang lain dalam sebuah pertunjukan drama. Wayang Beber merupakan bentuk ekspresi dari perilaku masyarakat yang digambarkan. Cara yang 
sama ini berarti mengacu kepada kesamaan yang berarti ada pertunjukan yang ditampilkan.

Goffman mengacu pada pertunjukan sosiologi. Pertunjukan yang terjadi di masyarakat untuk memberi kesan yang baik untuk mencapai tujuan. Tujuan dari presentasi dari diri - Goffman ini adalah penerimaan penonton akan manipulasi. Apabila seorang aktor berhasil, maka penonton akan melihat aktor sesuai sudut yang memang ingin diperlihatkan oleh aktor tersebut. Aktor dalam hal ini adalah dalang Wayang Beber, sehingga akan semakin mudah untuk membawa penonton mencapai tujuan dari pertunjukan tersebut.

Ini dapat dikatakan sebagai bentuk lain dari komunikasi. Karena komunikasi sebenarnya adalah alat untuk mencapai tujuan. Apabila di dalam komunikasi konvensional manusia berbicara tentang bagaimana memaksimalkan indera verbal dan non-verbal untuk mencapai tujuan akhir komunikasi agar orang lain mengikuti kemauan kita, maka dalam dramaturgis, yang diperhitungkan adalah konsep menyeluruh bagaimana kita menghayati peran sehingga dapat memberikan feedback sesuai yang kita mau. Perlu diingat kembali bahwa dramatugis mempelajari konteks dari perilaku manusia dalam mencapai tujuannya dan bukan untuk mempelajari hasil dari perilakunya tersebut. Dramaturgi memahami bahwa dalam interaksi antar manusia ada "kesepakatan" perilaku yang disetujui yang dapat mengantarkan kepada tujuan akhir dari maksud interaksi sosial tersebut. Memainkan beberapa peran dalam Wayang Beber dan mengkomunikasikannya kepada masyarakat merupakan salah satu cara yang dapat mengacu kepada tercapainya sebuah kesepakatan tertentu tersebut.

Satu kelompok masyarakat dengan nilai, norma, tradisi, adat, dan budaya yang sama akan mempunyai peninggalan masa lampaunya. Dalam masyarakat yang belum mengenal tulisan jejak-jejak masa lampaunya, akan disebarluaskan dan diwariskan secara turun temurun kepada generasi berikutnya secara lisan sehingga menjadi bagian dari tradisi bertutur (lisan).

Tradisi lisan mencakup segala hal yang berhubungan dengan sastra, bahasa, sejarah, biografi, dan berbagai pengetahuan, serta jenis kesenian lain yang disampai kan dari mulut ke mulut. Jadi, tradisi lisan tidak hanya mencakup cerita rakyat, teka-teki, peribahasa, nyanyian rakyat, mitologi, dan legenda sebagaimana umumnya diduga orang, tetapi juga berkaitan dengan sistem kognitif kebudayaan, seperti sejarah, hukum, dan pengobatan. Tradisi lisan adalah "segala wacana yang diucapkan atau disampai kan secara turun-temurun yang meliputi lisan dan yang beraksara" dan diartikan juga sebagai "sistem wacana yang bukan beraksara.". Tradisi lisan tidak hanya dimiliki oleh orang lisan saja. Implikasi kata "lisan" dalam pasangan lisan-tertulis berbeda dengan lisanberaksara. Lisan yang pertama (oracy) mengandung maksud 'keberaksaraan bersuara', sedangkan lisan kedua (orality) mengandung maksud kebolehan bertutur secara beraksara. Kelisanan dalam masyarakat beraksara sering diartikan sebagai hasil dari masyarakat yang tidak terpelajar; sesuatu yang belum dituliskan; sesuatu yang dianggap belum sempurna atau matang, dan sering dinilai dengan kriteria keberaksaraan, Pudentia (1999, p. 32).

Dalam tradisi lisan, peranan orang yang dituakan seperti kepala desa atau suku, ketua adat sangatlah penting. Mereka diberi kepercayaan oleh kelompoknya untuk memelihara dan menjaga tradisi yang diwariskan secara turun temurun

\section{Metode dan Data}

Penelitian ini akan menggunakan metode kualitatif, di dalamnya akan dicantumkan poin-poin penting mengenai prosesi persiapan pementasan Wayang Beber 
hingga usai. Penggunaan metode ini dinilai lebih tepat karena di dalamnya terdapat banyak data yang perlu didokumentasikan sebagai referensi pembentukan dramaturgi pementasan.

a. Sampel

Di dalam pengambilan sampel ini teknik yang dipergunakan adalah "nonprobability purposive sampling”, yaitu teknik pengambilan sampel yang didasarkan pada kondisi-kondisi atau karekteristik tertentu yang khusus (necessary condition) yang telah ditetapkan oleh penelititi (Dantes: 2012: 46). Maka sampel akan diambil dari beberapa pihak, Paling tidak dari empat kelompok masyarakat. Yang pertama adalah pelaku dan pemegang kesenian yaitu lingkungan keluarga Mbah Mardi sebagai Dalang Wayang Beber. Yang kedua adalah dari pemerintah daerah dalam hal ini bagian kebudayaan sebagai instansi yang bertugas memperhatikan segala peristiwa budaya di daerahnya. Yang berikutnya adalah seniman daerah yang berniat mengembangkan kesenian ini. Sedangkan yang terakhir adalah masyarakat sebagai pengamat atau pihak yang akan menerima produk kesenian ini.

Sebagaimana pendapat bahwa sampel adalah obyek dari populasi yang diambil melalui teknik sampling, yaitu cara-cara mereduksi obyek penelitian dengan mengambil sebagian saja yang dianggap representatif terhadap populasi

\section{b. Instrumen}

Instrumen yang dipergunakan berupa proses persiapan pementasan dan pementasannya, daftar pertanyaan, serta dokumentasi audio visual.

c. Jalan Penelitian

Data kualitatif diperoleh dengan cara melakukan:

1. Wawancara dengan keluarga dan kerabat Mbah Mardi sebagai pewaris kesenian Wayang Beber. Dari sana akan digali persoalan persoalan yang melatarbelakangi keberadaan Wayang Beber dahulu dan saat ini.

2. Rekaman foto-foto proses persiapan Wayang Beber dan saat pengambilan data wawancara dengan keluarga Mbah Mardi.

d. Variabel

Obyek penelitian ini adalah hasil survei, wawancara, dan rekaman, maupun foto-foto wawancara dan Wayang Beber Pacitan.

\section{e. Prosedur Pelaksanaan}

Dalam penelitian ini peneliti mengikuti metode pengumpulan data yang merupakan suatu cara yang digunakan atau dipakai untuk memperoleh data yang dipakai untuk memecahkan masalah yang akan diteliti. Dalam hal ini metode yang dipilih harus sesuai dan mempunyai alasan pemakaian yang kuat. Metode-metode yang digunakan dalam penelitian ini adalah sebagai berikut:

\section{Studi Pustaka}

Data mengenai keberadaan Wayang Beber Pacitan bisa diperoleh dari buku serta hasil penelitian para peneliti terdahulu semisal desertasi. Beberapa kisah tentang Wayang Beber ini ditulis dalam sebuah manuskrip baik berupa tembang atau serat. Beberapa penulis sudah pernah meneliti sehingga layak untuk menjadi bahan pertimbangan.

\section{Teknik Wawancara dan Observasi}

Sebelum dan sesudah melakukan pengamatan perlu dilakukan tanya jawab atau wawancara terhadap berbagai pihak yang berkaitan. Menurut Ratna (2010, pp. 222223), wawancara melibatkan dua komponen, pewawancara yaitu peneliti itu sendiri dan orang-orang yang diwawancarai. Secara khusus, informan dan responden adalah individu-individu yang aktif, bukan Pasif, 
memahami situasi sesuai dengan horizon harapannya, dengan masa lampau dan masa kininya hal ini untuk mengetahui sejauh mana mereka menangkap fenomena pertunjukan yang disajikan sehingga membuka kemungkinan-kemungkinan baru dalam memaknai peristiwa pertunjukan Wayang Beber tersebut. Sutrisno Hadi (1980, p. 136), menjelaskan bahwa observasi diartikan sebagai pengamatan dan pencatatan dengan sistematik fenomena-fenomena yang diselidiki dan tidak hanya terbatas pada pengamatan yang dilakukan baik secara langsung maupun tidak langsung.

\section{f. Mendeskripsikan proses penelitian}

MendeSekartajiripsikan suatu proses kegiatan kesenian berdasarkan apa yang terjadi di lapangan sebagai bahan kajian lebih lanjut untuk menemukan dan mengenali kekurangan dan kelemahan pertunjukan sehingga dapat ditentukan upaya penyempurnaannya.

Menganalisis dan menafsirkan suatu fakta, gejala, dan peristiwa pertunjukan tersebut yang terjadi sebagaimana adanya dalam konteks ruang dan waktu serta situasi lingkungan peristiwa kesenian itu secara alami. Metode analisis data yang digunakan dalam penelitian ini adalah metode analisis data kualitatif yang disajikan secara deskriptif. Menurut Moleong (2009: 248) analisis data kualitatif adalah upaya yang dilakukan dengan cara mengorganisasikan data, memilah-milah data menjadi satuan yang dapat dikelola, mensintesiskannya, mencari dan menemukan pola, menemukan apa yang penting dan apa yang dipelajari, dan memutuskan apa yang dapat diceritakan kepada orang lain.

Tahap terakhir adalah menyusun hipotesis berkenaan dengan konsep dan prinsip berkesenian berdasarkan data dan informasi yang terjadi di lapangan (induktif) untuk kepentingan pengujian lebih lanjut.

\section{Hasil dan Pembahasan}

\section{Analis is struktur}

Dalam pertunjukan Wayang Beber Jaka Kembang Kuning mempunyai kerangka cerita yang digunakan oleh dalang untuk menyampaikan isi dan pesan moral. Cerita tidak digambarkan melalui tulisan namun melalui gambar yang ditorehkan oleh pelukis wayang pada media berupa kertas. Satu gulung kertas cerita berisi 4 adegan (jagong). Kerangka cerita termasuk struktur yang menyusun pertunjukan tersebut, struktur merupakan komponen utama, dan merupakan (unity of action) dalam drama (Satoto, 2012, p. 38)

Dalam setiap adegan mempunyai tensi dramatik tersendiri yang merupakan bagian bangunan sebuah cerita drama yang terstruktur. Secara keseluruhan struktur merupakan komponen yang paling utama, dan merupakan (unity of action) dalam drama (Satoto, 2012, p. 38).

1. Struktur utama yang perlu kita lihat adalah tema atau gagasan utama dalam sebuah cerita. Jalinan cerita secara runtut dari awal sampai akhir sebagaimana penulis naskah lakon menciptakan untuk menyuguhkan persoalan hidup manusia, baik kehidupan lahiriyah maupun kehidupan batiniah, yaitu pikiran (cita), perasaan (rasa), dan kehendak (karsa), (Satoto 2012:39), dalam hal ini terlukis dalam gambar Wayang Beber di keempat gulungannya.

Tema dalam Wayang Beber Jaka Kembang Kuning ini adalah romantika percintaan Dewi Sekartaji dan Jaka Kembang Kuning. Liku-liku kisah cinta seorang putri Kerajaan Kediri yang menolak dijodohkan dengan seorang tidak dicintainya. Sang putri terpaksa melarikan diri agar kehormatan orang tuanya tetap terjaga karena perjodohan yang harus dihadapi mempunyai 
konsekwensi berat pada ketenteraman Kerajaan Kediri karena lelaki yang dijodohkan adalah seorang raja yang bersifat angkara murka ingin menguasai negerinya dengan kekerasan. Dalam hal ini Sekartaji merupakan sosok perempuan pemberontak sekaligus bertanggung jawab pada negerinya selaku seorang putri raja Namun begitu sebagai seorang anak manusia ia juga memiliki rasa cinta dan rindu akan kebebasan.

\section{Alur}

Jalinan yang sambung menyambung dari awal sampai akhir dan menjadi sebuah kesatuan cerita merupakan salah satu unsur bangunan dramatik. Alur atau plot bisa disebut metafora aksi yang mengikuti pola baik literal maupun figuratif dari kehidupan nyata. Pola ini mungkin berupa perjuangan menuju akhir (finish) antara tokoh hero dalam memerangi kejahatan, (Cahyaningrum, 2012, p.169). Diawali dari kepergian Sekartaji lalu pertemuan dengan Jaka Kembang Kuning, dilanjutkan dengan peperangan memperebutkan mempelai, yang diakhiri dengan kemenangan salah satu pihak, merupakan jalinan cerita yang lurus dan sambung menyambung. Semua merupakan penyusunan insiden-insiden yang terjadi (Kernodle, 1978, p. 265). Sehingga dapat dikatakan alur cerita ini linier.

Pada cerita Wayang Beber Panji Jaka Kembang Kuning terdapat beberapa urutan peristiwa yang mengandung tensi permainan yang berbeda-beda atau disebut struktur dramatik yang menurut Aristoteles disebut: eksposisi, komplikasi, klimaks dan resolusi.

a) Pada fase eksposisi diceritakan dalam gulungan pertama jagong satu sampai dengan enam. Di sini diceritakan tentang Sekartaji yang sudah menjadi kekasih Panji Asmarabangun putra Raja Jenggala, melarikan diri dari istana karena menolak untuk dijodohkan dengan Prabu Klana. Maka dibuatlah sayembara untuk menemukan Sekartaji kemudian Panji Asmarabangun menyamar sebagai rakyat biasa datang ke kerajaan untuk mengikuti sayembara itu. Sementara utusan raja atau Prabu Klana yang bernama Kebo Lorodan gagal melamar Sekartaji karena menghilang. Dalam pelarian tersebut akhirnya Sekartaji ditemukan oleh Panji Asmarabangun yang menyamar sebagai rakyat biasa bernama Jaka Kembang Kuning. Jaka Kembang Kuning lalu mengabarkan penemuannya melalui utusannya, Tawang Alun, ke Raja Kediri.

\section{b) Komplikasi}

Komplikasi dimulai saat Raja Klana menyampaikan mahar perkawinan untuk Sekartaji melalui utusannya yang bernama Retno Tegaron namun ditolak oleh Retno Mindaka (pembantu Sekartaji) hingga berakhir pada perkelahian kedua pihak. Sementara itu berita penemuan Sekartaji yang dibawa oleh Tawang Alun bocor ke telinga pihak Raja Klana. Maka Raja Klana mendahului bertemu dengan Raja Kediri untuk menagih lamarannya. Ditengah pertemuan itu datanglah Tawang Alun menyampaikan laporannya. Akhirnya Raja Kediri memututuskan untuk menggelar perang tanding antara kedua belah pihak memperebutkan Sekartaji. Peristiwa ini digambarkan dalam jagong tujuh sampai sepuluh.

\section{c) Klimaks}

Puncak ketegangan terjadi pada saat digelarnya peperangan antara pihak Prabu Klana dan Jaka Kembang Kuning. Perang tanding terjadi dua kali dan diakhiri dengan perang besar. Perang tanding pertama dimenangkan oleh pihak Prabu Klana yang diwakili oleh Kebo Lorodan mengalahkan Tawang Alun. Perang tanding dua dimenangkan oleh Jaka Kembang Kuning mengalahkan Kebo Lorodan. Di tengah peperangan berlangsung, Prabu Klana 
menyelinap menemui Sekartaji dengan menyamar sebagai Gandarepa (Kakak Sekartaji). Namun hal itu gagal dan membuat dirinya mengambil keputusan untuk perang melawan kediri. Maka terjadilah perang besar sehingga Raja Klana tewas di ujung keris Tawang Alun.

d) Bagian ini disebut resolusi dimana diceritakan bahwa wanita-wanita dari pihak Raja Klana diboyong ke Kediri lalu setelah persidangan di Istana Kediri maka perkawinan Sekartaji dan Panji Asmarabangun dilangsungkan. Sekartaji akhirnya diboyong oleh Panji Asmarabangun (Jaka Kembang Kuning) ke Jenggala. Ini merupakan bagian terakhir atau juga bisa disebut pemecahan masalah.

\section{Penokohan}

Semua tokoh-tokoh yang ada dalam cerita menurut gambar pada wayang beber adalah:

Raja Kediri, Panji Asmarabangun (Jaka Kembang Kuning), Raja Klana, Dewi Sekartaji, Senopati Kediri Sedah Rono, Patih Arya Deksa Negara, Tawang Alun, Nala Derma, Tumenggung Cona-Cani, Ni Cona CaniKi Demang Kuning, Retno Mindaka (Adik Raja Kediri), Retno Tegaron (Adik Raja Klana), Ni Pengilon (Dayang-Dayang Retno Mindaka), Ni Mancung (DayangDayang Retno Mindaka), Gandarepa (Putra Raja Klana), Senopati Sedahrama (Panglima Raja Kediri), Kili Suci (Kakak Raja Kediri)

Dalam gambar Wayang Beber tokohtokoh bisa saling berseberangan. Tokohtokoh tersebut dapat dibedakan menjadi beberapa golongan antara lain protagonis (tokoh yang membawa ide atau tema yang menjadi pusat perhatian), antagonis (tokoh yang menentang ide yang dibawa tokoh protagonis), tritagonis (tokoh penengah atau perantara protagonis dan antagonis) dan peran pembantu (peran yang tidak secara langsung terlibat dalam konflik, tetapi diperlukan guna menyelesaikan cerita), (Harymawan 1998, p. 22), seperti terlihat pada tabel di bawah ini.

\begin{tabular}{|l|l|l|l|}
\hline \multicolumn{1}{|c|}{ Protagonis } & \multicolumn{1}{|c|}{ Antageais } & \multicolumn{1}{c|}{ Tritagenis } & \multicolumn{1}{c|}{ Pembanta } \\
\hline $\begin{array}{l}\text { Pa (Jaka Kembang } \\
\text { Kuning) }\end{array}$ & Raja Klana & Raja Kediri & $\begin{array}{l}\text { Ni Pengilon (Danang- } \\
\text { Dayang Retno } \\
\text { Mindaka) }\end{array}$ \\
\hline Sekartaji & $\begin{array}{l}\text { Gandarepa (Putra } \\
\text { Raja Klana) }\end{array}$ & $\begin{array}{l}\text { Patih Arya } \\
\text { Deksa Negara }\end{array}$ & $\begin{array}{l}\text { Ni Mancung } \\
\text { (Dayang-Dayang } \\
\text { Retro Mindaka) }\end{array}$ \\
\hline $\begin{array}{l}\text { Tawang Alun } \\
\text { (Adik Raja Kediri) }\end{array}$ & $\begin{array}{l}\text { Retno Tegaron } \\
\text { (Adik Raja Klana) }\end{array}$ & $\begin{array}{l}\text { Ki Demang } \\
\text { Kuning }\end{array}$ & $\begin{array}{l}\text { Gandarepa (Putra } \\
\text { Raja Klana) }\end{array}$ \\
\hline & $\begin{array}{l}\text { Tumenggung } \\
\text { Cona Cani }\end{array}$ & $\begin{array}{l}\text { Senopati Sedahrama } \\
\text { Ni Cona Cani }\end{array}$ & $\begin{array}{l}\text { Kili Suci (Kakak Raja } \\
\text { Kediri) }\end{array}$ \\
\hline & & & Nali Derma \\
\hline
\end{tabular}

Tabel 1 penggolongan tokoh berdasar posisi konflik dalam cerita

\section{Latar}

Setting atau latar cerita yaitu bagian dari teks dan hubungan yang mendasari suatu lakuan (action) terhadap keadaan sekeliling. (Satoto, 2012, p. 55). Wayang Beber Jaka Kembang Kuning ini berlatar belakang tempat di Kerajaan Kediri di Jawa. Sedangkan waktu berlangsungnya kejadian menurut cerita diperkirakan sekitar abad ke12 M. Setting merupakan jalinan setiap bentuk cerita.

\section{Analisis Tekstur}

Tekstur pertunjukan teater mencakup dialog, musik suasana, dan spektakel. Tekstur adalah yang dirasakan langsung penonton atau yang datang kepadanya lebih kepada rasa, apa yang telinga dengar (dialog), apa yang mata lihat (spektakel), dan apa itu perasaan sebagai suasana selama pertunjukan, dalam pengalaman dari dalam (mood). Tekstur merupakan sarana dalam membawakan cerita, sehingga hal itu tergantung pada selera dan aspek estetika tersendiri (Kernodle, 1978, p. 256).

Pada lakon Wayang Beber Jaka Kembang Kuning, dialog diucapkan oleh satu orang saja yaitu sang dalang. Dalam menyampaikan dialog dipergunakan Bahasa 
Jawa halus dan mempunyai nilai sastra tinggi. Selain menggunakan dialog, sang dalang juga menggunakan nyanyian atau tembang untuk menggambarkan peristiwa cerita. Selain itu, ruang atau waktu yang tidak terlihat secara detail dalam gambar akan diceritakan secara lisan maupun lagu. Dalam beberapa peristiwa dalam adegan yang mempunyai tekanan dramatik tersendiri, dalang justu mempergunakan silent atau juga bisa dengan iringan musik tertentu.

Musik hanya diputar dengan nada monoton (menggunakan gamelan slendro), perbedaan terjadi hanya pada perubahan tempo saja. Dalam adegan-adegan yang membutuhkan penekanan emosi tertentu, maka tempo permainan musik bisa melambat atau justru cepat. Suasana permainan lebih cenderung pada suasana yang membosankan namun dinilai penuh aura mistis. Hal tersebut terjadi karena iringan musik yang monoton, tembang dengan nada monoton, pencahayaan yang minim sekali (hanya dengan satu buah lampu blencong), gambar yang relatif stagnant, ditambah lagi ubarampe atau sesajen yang terdiri dari jadah jojoh yang ditumpangi ayam bekakak (utuh) bakar, diletakkan di depan area permainan (Wayang Beber digelar).

Seluruh pertunjukan yang bersifat audio visual berjalan dengan penuh khidmat tanpa adanya peristiwa yang bersifat mencairkan suasana, semisal lawak, lagu hiburan, dialog dengan audience, dan sebagainya. Dapat dikatakan bahwa pertunjukan hanya berlaku satu arah saja. Dalang aktif bercerita sedangkan penonton secara pasif menyaksikannya. Tidak seperti wayang kulit atau kesenian lain dimana dalang bisa berinteraksi langsung, baik dengan sesama performer maupun penonton.

\section{Problematika Pementasan}

Wayang Beber dengan pola pementasan yang sedemikian monoton tidak mampu memperoleh perhatian yang banyak dari penonton. Selain itu, pertunjukan ini sangat bernuansa eksklusif karena ada unsur politis yang dibangun pelaku seninya sendiri. Masyarakat pendukungya menganggap Wayang Beber merupakan pusaka desa yang dikeramatkan, sehingga tidak sembarang orang boleh mementaskan selain trah (keturunan) dalang Wayang Beber itu sendiri. Wayang Beber tidak lagi berfungsi sebagai sarana hiburan semata, namun telah berubah menjadi sarana ritual tersendiri. Wayang Beber difungsikan untuk mewujudkan nazar (KBBI: janji pada diri sendiri), misalnya apabila anggota keluarganya sakit dan bisa disembuhkan maka akan nanggap Wayang Beber. Selain itu Wayang Beber Jaka Kembang Kuning juga dipergunakan untuk sarana ritual pada bagian tertentu di acara bersih desa tempat Wayang Beber tersebut berada. Maka dapat dilihat bahwa kesenian ini selain menjadi sarana ritual otomatis juga merupakan sarana hiburan dan sebaliknya, bahkan secara politis telah dimanfaatkan untuk memperoleh keuntungan secara ekonomi.

In ancient Athens, the great theatre festivals were ritual, art, sports-like competition, and popular entertainment simultaneously. Today, sport are both live and media entertainment combining competition, ritual, and big business. (Schechner, 2002, p. 26)

Akibat dari perlakuan yang terlampau tertutup tersebut, maka Wayang Beber tidak bisa berkembang. Sedangkan tidak semua keturunan dalang mempunyai minat dan bakat untuk mengelola dan memainkannya. Akibat dari pementasan yang dipaksakan secara politis dan tanpa memperhatikan kwalitas tersebut antara lain,

a. Beberapa tembang menjadi kehilangan nada-nada tertentu secara bertahap dibandingkan pendahulunya,

b. Peristiwa yang terlukis di kertasnya mulai banyak yang tidak dikisahkan oleh sang 
dalang. Beberapa alasan yang dikemukakan oleh Supani diantaranya karena etika yang tidak pas dg konteks dia berada serta kapasitas dalang yang kurang inovatif dalam membawakannya misalnya masih membaca teks contekan.

c. Dalang yang baru tidak mampu mengucapkan kata-kata dengan sastra yang baik, sebaik pendahulunya. Karena bahasa yang kurang familiar baginya dan bagi penonton.

d. Gulungan Wayang Beber semakin rusak karena tidak boleh diduplikasi ulang. Meskipun telah diduplikasi, pihak keluarga tidak mengakui sebagai pusaka sebagaimana gulungan asli yang diwariskan turuntemurun, Padahal kondisinya semakin memprihatinkan karena telah lapuk dimakan cuaca dan lamanya usia sehingga gambar semakin kabur dan kertas banyak yang robek. e. Musik tidak berkembang baik dari jumlah alat yang dipergunakan maupun jenis gending atau irama yang dibawakan.

f. Beberapa peristiwa justru menimbulkan polemik dalam keluarga dalang itu sendiri terutama apabila salah seorang anggota keluarga mampu memainkannya sedangkan anggota lain tidak. Sehingga bisa mendatangkan keuntungan secara finansial dari mementaskan Wayang Beber tersebut. Hal ini menumbuhkan rasa iri pada anggota keluarga yang lain.

Meski demikian telah dibuat kesepakatan agar Wayang Beber dipegang secara bergilir oleh seluruh kuturunan dalang pada tiap periodesasi tertentu, karena tidak semua anggota mampu memainkannya. Uang hasil pementasan yang dilakukan oleh anggota keluarga yang bisa mendalang harus disisihkan dan dibagikan kepada anggota keluarga yang lain secara merata. Setiap kali Wayang Beber kembali kepada anggota keluarga yang bisa mendalang, maka anggota keluarga itu akan memainkan Wayang Beber di muka umum (mulih).

\section{Simpulan}

Wayang Beber Jaka Kembang Kuning merupakan seni tradisi lisan yang mempunyai alur tangga dramatik seperti tangga dramatik Aristotelian. Pada setiap peristiwa cerita terdapat tekanan-tekanan yang dinamis dengan ditandai puncakpuncak kecil tangga dramatik di setiap gulungan cerita secara progresif. Meskipun cerita tersebut masih bisa terbilang bernuansa hitam-putih serta intrik-intrik permasalahan yang tergolong sederhana. Tokoh-tokoh di dalamnya mempunyai karakter yang jelas dan menggambarkan sosok jahat dan baik, keras dan lembut, dan sejenisnya.

Namun demikian cerita dalam gulungan hanyalah sebuah "teks mati" yang seharusnya bisa dihidupkan melalui tangan sang dalang agar menjadi pertunjukan menarik. Pada kenyataan yang terjadi, beberapa pementasan yang dilakukan dalang kurang mampu menyajikan seluruh dinamika cerita secara utuh. Dalam membawakan pertunjukan sang dalang terjebak pada aturan-aturan sosial maupun kultural yang melingkupinya sehingga menghambat kreatifitasnya. Terlihat pada pertunjukan yang tidak menarik dan cenderung membosankan. Dalang hanya mewarisi cara yang telah dilakukan oleh pendahulunya tanpa berusaha mendekatkan pada konteks kekinian di mana dalang dan penonton berada. Mungkin saja teknik dan bahasa jawa kuno yang dipakai dalang terdahulu cocok pada zamannya, namun generasi saat ini sudah banyak yang tidak memahaminya. Meskipun sudah digunakan alat musik sebagai pendukung pementasan, namun penggunaannya belum maksimal dan cenderung terjebak pada pola-pola yang berulang-ulang tanpa progresi tertentu yang jelas. Permainan iramanya tidak memberikan tekanan-tekanan yang dibutuhkan cerita dalam mendramatisasi pertunjukan.

Fungsi ritual yang membuat masyarakat mensakralkannya akan semakin 
luntur seiring perkembangan tehnologi informasi yang deras dan cepat. Keharusan menghadirkan sesaji dan syarat-syarat ritual tertentu sebelum permainan dimulai membatasi ruang gerak bagi orang yang akan menyelenggarakannya. Bagi generasi saat ini akan sulit untuk menemukan sarana ritual yang lengkap karena sudah mengalami kelangkaan di pasar.

Hal lain yang masih menjadi penghambat bagi kesenian untuk maju adalah adanya nuansa politis di seputar keluarga pewarisnya. Hal ini menjadikan kesenian tersebut semakin terpinggirkan karena tidak boleh dimainkan secara bebas oleh pihak di luar keluarga pewarisnya. Apabila Wayang Beber ini bisa dimainkan oleh banyak pihak (tidak hanya oleh ahli waris/keluarga saja) tentu ide-ide akan banyak mengalir di dalamnya yang akan memperkaya permainannya. Secara singkat, selain secara estetis ternyata juga terdapat hal-hal yang bersifat politis serta kultural yang menghambat kesenian Wayang Beber Jaka Kembang Kuning untuk berkembang.

\section{Daftar Pustaka}

Dantes, N. (2012). Metode Penelitian. Penerbit Andi.

Hadi, S. (1980). Metodologi Riset. Penerbit Fakultas Psikologi Universitas Gadjah Mada.

Harymawan. (1998). Dramaturgi. Remaja Rosdakarya.

Hauskeller, M. (2015). Seni-apa itu?: posisi estetika dari Platon sampai Danto. Penerbit Kanisius.

Hutomo, S. S. (1991). Mutiara yang terlupakan: Pengantar studi sastra lisan. Himpunan Sarjana Kesusastraan Indonesia, Komisariat Jawa Timur.

Kernodle. G. R. (1978). Invitation to The Theatre. Harcourt Brace Jovanovic.

Kutha Ratna, N. (2011). Teori. Metode, dan Teknik Penelitian Sastra-dari
Strukturalisme hingga

Poststrukturalisme Perspektif Wacana

Naratif Yogyakarta. Pustaka Pelajar.

Moleong. L. J. (1997). Metodologi Penelitian

Kualitatif. Remaja Rosdakarya

Mulyana. D. (2003). Metodologi Penelitian

Kualitatif. Rosda Karya.

Pudentia, M. P. S. S. (Ed.). (2015).

Metodologi kajian tradisi lisan (edisi

revisi). Yayasan Pustaka Obor Indonesia.

Ratna, N. K. (2019). Metodologi penelitian kajian budaya dan ilmu sosial humaniora pada umumnya. Pustaka Pelajar.

Sahid. N. (2008). Sosiologi Teater. Prasista. Satoto. S. (2012). Analisis Drama \& TeaterI, Analisis Drama \& Teater II. Ombak.

Sawega, A. M. (Ed.). (2013). Wayang beber: Antara inspirasi dan transformasi. Bentara Budaya Balai Soedjatmoko.

Schechner, R. (2002). Performance Studies, An Introduction. Routledge

Sutyasmono, Y. (2013). Wayang Beber, Antara Inspirasi dan Transformasi. Bentara Budaya Balai Soedjatmoko.

\section{Lampiran}

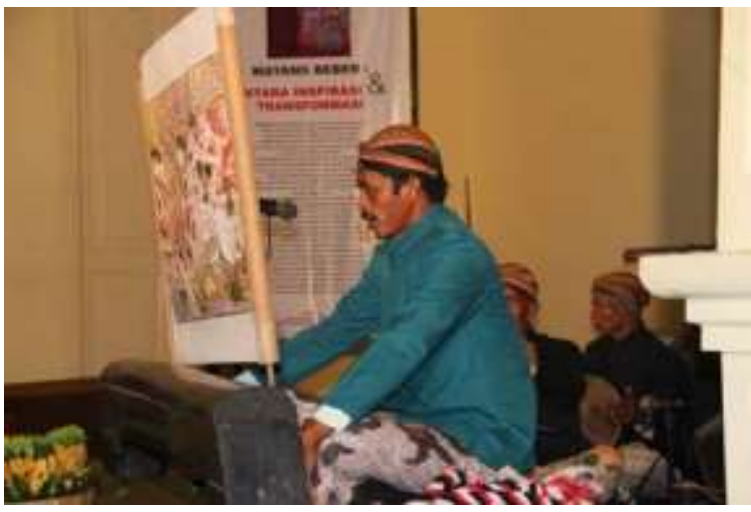

Gambar 1 Pementasan Wayang Beber oleh Dalang Supani (foto: Dinas Pariwisata Pacitan) 


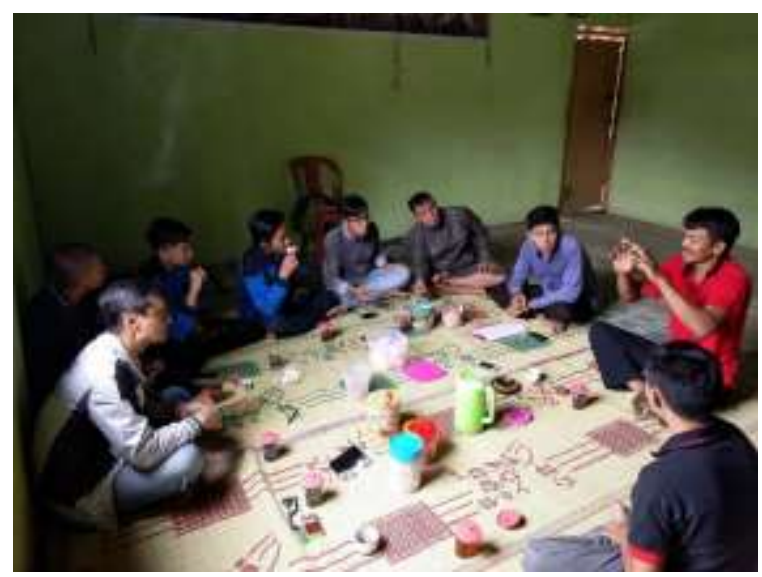

Gambar 2 Wawancara dengan Supani Dalang pewaris Wayang Beber (Foto: Wahid)

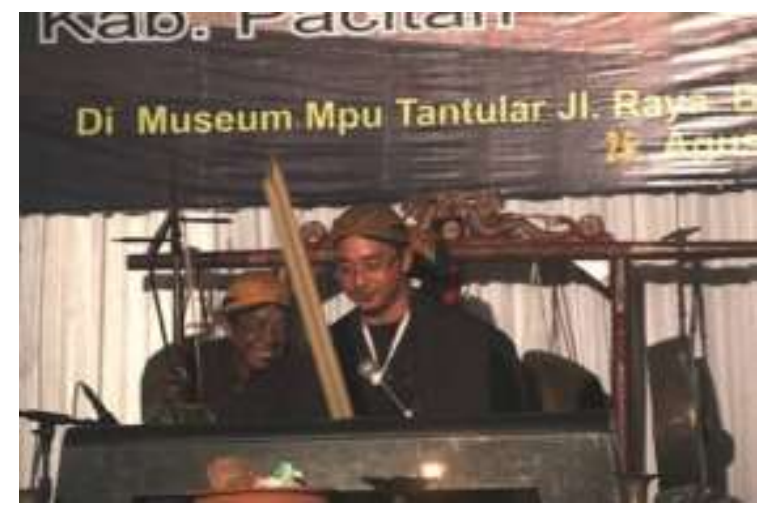

Gambar 3 Pementasan Wayang Beber oleh Rudi di Museum Mpu Tantular (foto: Rudi) 